\title{
Stem Cells in Regenerative Medicine
}

\author{
Eva Sykova ${ }^{1,2}$ and Serhiy Forostyak ${ }^{1}$ \\ 1: Department of Neuroscience, Institute of Experimental Medicine, \\ Academy of Science of the Czech Republic, Videnska 1083, Prague, 14220, Czech Republic \\ 2: Department of Neuroscience, 2nd Faculty of Medicine, Charles University, \\ V Uvalu 84, Prague, 15006, Czech Republic
}

\begin{abstract}
Background: A number of cardiovascular, neurological, musculoskeletal and other diseases have a limited capacity for repair and only a modest progress has been made in treatment of brain diseases. The discovery of stem cells has opened new possibilities for the treatment of these maladies, and cell therapy now stands at the cutting-edge of modern regenerative medicine and tissue engineering. Experimental data and the first clinical trials employing stem cells have shown their broad therapeutic potential and have brought hope to patients suffering from devastating pathologies of different organs and systems.

Aims: Here, we briefly review the main achievements and trends in cell-based therapy, with an emphasis on the main types of stem cells: embryonic, mesenchymal stromal and induced pluripotent cells.

Discussion: Many questions regarding the application of stem cells remain unanswered, particularly tumorigenicity, immune rejection and danger of gene manipulation. Currently, only MSC seems to be safe and might be considered to be a leading candidate for human application to treat pathologies that affect the cardiovascular, neurological and musculoskeletal systems.
\end{abstract}

Key words: Stem Cells • Embryonic Stem Cells • Mesenchymal Stromal Cells • Induced Pluripotent Stem Cells • Clinical Trials • PACS: 87.19.L-; 87.19.LW

\section{Introduction}

The progress made in science and medicine in the last decades has significantly improved the level of healthcare, leading to an increased quality of life and an extended lifespan. However, a variety of factors in our daily life such as urbanization, the aging of the population, exposure to a toxic environment, bad habits, hypoactivity, inappropriate diet and trauma have caused annual increases in the number of people suffering from cardiovascular, neurological, neurodegenerative [amyotrophic lateral sclerosis (ALS), multiple sclerosis (MS), Alzheimer's disease (AD), Parkinson's disease (PD) etc.], osteoarthritic and endocrine pathologies. Most of the above disorders affect the nor-

\section{Addressee for Correspondence:}

Prof. Eva Sykova, M.D., Ph.D., D.Sc.

Department of Neuroscience Institute of Experimental Medicine AS CR Videnska 1083, 142 20, Prague 4 Czech Republic

Tel. +420241062 230, Fax. +420241062706

E-mail addresses: sykova@biomed.cas.cz (E. Sykova) mal lifestyle of the afflicted individual and often result in invalidity, requiring lifelong care and symptomatic treatment, as well as having an enormous impact on the patient's family and financial situation. Therefore, current research is focused on degenerative disorders, the common feature of which is the dysfunction and death of certain cell types. Considering that all the cells in the human organism have a common origin, it is believed that degenerative diseases might be treated by the application of stem cells (SC), which can provide trophic support or even replace dying cells with new ones.

The discovery of SC represents the cutting-edge of modern biology. The detailed characterization of the properties of SC logically raised the question of their use as a therapeutic agent in regenerative medicine. Stem cells are classified by their source and the tissue they are typically generated from: 1) human embryonic stem cells (ES); 2) fetal stem cells; 3) somatic (adult-

Received Date: March 2nd, 2013

Accepted Date: June 3rd, 2013 
derived) stem cells; and 4) induced pluripotent stem (iPS) cells. iPS cells have recently been shown to regain their pluripotent properties after the artificial introduction of transcriptional factors into a somatic cell ${ }^{1)}$. The importance of the discovery of iPS cells was recognized by the awarding of the Nobel Prize in Physiology or Medicine in 2012 to Sir John B. Gurdon and Shinya Yamanaka. Considering the ability of stem cells to provide an enormous source of cells and their multi/pluripotency, they represent an excellent candidate for modeling and studying various pathologies as well as for the cell-based therapy of degenerative diseases; in addition, they are capable of long-term survival following transplantation.

\section{Human embryonic and fetal stem cells}

Embryonic stem cells (ES) are derived from the inner cell mass of blastocyst-stage embryos and are characterized by their capacity to remain proliferative in an undifferentiated state for a prolonged period in culture and to differentiate into several different somatic cell types ${ }^{2)}$. The first experimental studies aimed at treating degenerative diseases or traumatic injury of the CNS used fetal or embryonic tissue in order to isolate various types of stem or progenitor cells, including ES, neural stem cells (NS), spinal precursor cells etc. ${ }^{3-9)}$. The transplantation of human ES (at both early and later stages of differentiation) can promote functional, behavioral and morphological improvement in experimental animals; however, there are reports describing hyperproliferation and the formation of teratomas after grafting ${ }^{10)}$. For the treatment of CNS disorders, a successful neuronal replacement would necessitate the formation of long tracts of axonal outgrowth and the formation of synapses at neuromuscular junctions by the grafted cells. So far, only a few studies have demonstrated the establishment of functional connections between grafted embryonic stem cells and the host muscles after transplantation in animal models of acute injury of the peripheral nerves ${ }^{11-13)}$. Thus, the generation and grafting of support cells aimed at protecting the remaining host motoneurons might be more realistic and effective. Tissue engineering with ES is not only limited to CNS disorders; a number of studies have reported the successful application of ES for cartilage repair, as a biological pacemaker in cardiac regenerative medicine, peripheral nerve repair etc. ${ }^{14-17)}$

Another approach to regenerative medicine is the application of region-specific stem cell lines generated from fetal tissues, since these cells demonstrate higher proliferation, more specific differentiation, better migration after transplantation, as well as better regeneration ${ }^{18,19)}$. Probably the most significant effect of the transplantation of human fetal stem cells has been reported using a rat model of Parkinson's disease. Functional integration of grafted fetal dopamine neurons into the host brain and improved motor function in a rodent model became the basis for clinical trials in which the same effects were also observed in patients 20-22). Pollock et al. has reported that the transplantation of human cortical neuroepithelial stem cells derived from fetal cortical brain tissue into a rat model of stroke is safe, does not cause tumorigenicity, promotes the recovery of lost functions and is safe to progress to clinical trials ${ }^{23}$ ). We can conclude that the results achieved with the use of embryonic and fetal stem cells are at the forefront of current research; however, ethical considerations, a high risk of tumorigenesis and restricted access limit the utility of these cells for routine clinical application in patients.

\section{Mesenchymal stromal cells (MSC)}

Considering the above concerns about ES clinical usage, as well as the quite routine use of bone marrow to treat hematological diseases, MSC seem to be an ideal candidate for cellular therapy. MSC can be isolated from the bone marrow, and these cells are among the best characterized and most widely used in clinical practice; alternatively, MSC could be isolated from other tissues, such as fat tissue ${ }^{24)}$. Among the cell types with multipotent properties, MSC could be used for autologous transplantation, thus eliminating the risk of graft-versus-host disease (GVHD) and avoiding the use of cytostatics. MSC are hypoimmunogenic, interfere with dendritic cell maturation, modulate cytokine production and T-cell responses, inhibit inflammation and the production of the extracellular matrix, secrete soluble factors to create an immunosuppressive milieu and, if transplanted into an allogeneic host organism, do not induce an immune response or tumor formation. Regardless of the tissue of origin, all MSC can differentiate in vitro into chondrocytes, osteocytes, muscle cells, adipocytes or even neurons and glia ${ }^{25-27)}$; therefore, these cells should be primarily considered as a tool for successful therapy. It has been demonstrated that the plasticity (the ability of a cell to change its default fate) and tissue regenerative potential of bone marrow MSC may far exceed their use in hematopoietic diseases. The administration of MSC induces the secretion of growth factors by the host cells (paracrine function), such as brain-derived neurotrophic factor (BDNF), vascular endothelial growth factor (VEGF), neural growth factor (NGF), glia cell-line derived neu- 
rotrophic factor (GDNF) and IGF-1, that could target affected cells and thus influence regenerative processes 28-32).

Taking together the above features of MSC, we may speculate that these cells might be a tool that could be used in regenerative medicine for the treatment of degenerative diseases. Of special interest are neurological and neurodegenerative disorders, since they are the most challenging and lack effective therapies due to the limited plasticity of the CNS ${ }^{33)}$. In vivo experiments using different models of spinal cord injury and employing MSC alone or in combination with biomaterials revealed significant functional recovery of paralyzed limbs, reduced cavity formation in the spinal cord and better axonal regrowth through the glial scar 24, 34-40). Different methods of MSC application have also modified the disease course and animal survival in rodent models of ALS, Parkinson's disease, stroke, myocardial infarction, diabetic foot neuropathy etc. ${ }^{41-46)}$

The above properties of MSC led to the first preclinical and clinical trials, initially to treat myocardial infarction and later to treat stroke, ALS, PD and other diseases of the CNS ${ }^{47,48)}$. These trials showed that MSC transplantation is a safe procedure that brings benefits for the patients 34, 49-51). Autologous MSC transplantation also has been shown to have a positive effect on patients with a severe cerebral infarct ${ }^{48)}$. As a result, growing interest in cell therapy approaches utilizing MSC has made these cells among the leading candidates for human application, and new trials are on the way to test these cells in patients. For example, a three year prospective, non-randomized, open label clinical trial was launched in March 2012 in Prague (Czech Republic) aimed at assessing the safety and efficacy of autologous multipotent MSC to treat patients with a confirmed diagnosis of ALS

\section{References}

1: K. Takahashi and S. Yamanaka, Cell 126 (4), $663-$ 676 (2006)

2:. J. A. Thomson, J. Itskovitz-Eldor, S. S. Shapiro, M. A. Waknitz, J. J. Swiergiel, V. S. Marshall and J. M. Jones, Science 282 (5391), 1145-1147 (1998).

3: C. P. Hofstetter, E. J. Schwarz, D. Hess, J. Widenfalk, A. El Manira, D. J. Prockop and L. Olson, Proc Natl Acad Sci U S A 99 (4), 2199-2204 (2002).

4: L. Xu, J. Yan, D. Chen, A. M. Welsh, T. Hazel, K. Johe, G. Hatfield and V. E. Koliatsos, Transplantation (http://www.sukl.eu). Nevertheless, significant hurdles still remain before these and future findings could be responsibly translated to novel therapies.

\section{Induced pluripotent stem cells (IPS)}

Induced pluripotent stem cells can be generated from lineage-restricted cells through the ectopic expression of defined transcriptional factors ${ }^{1)}$. Similarly to ES, iPS are able to differentiate into advanced derivatives of all three primary germ layers - ectoderm, endoderm and mesoderm. iPS have been shown to differentiate towards a neuronal phenotype (motoneurons, dopaminergic and cholinergic neurons), cardiomyocytes, etc., leading to functional improvement after their application in animal models of PD, myocardial infarction, stroke, type I diabetes mellitus and other pathologies 52-55). Having said this, one should not underestimate the risk of genetic modification of both donor and host cells related to the transplantation of iPS cells, which are generated by the transfection of a viral vector, and probably the time is not yet ripe for their use in humans ${ }^{56}$ ). Nevertheless, iPS cells are an extremely useful tool for basic research in studying the pathology of different diseases, as well as in the development and screening of new drugs.

\section{Conclusions}

Stem-cell based regenerative medicine has opened new avenues for therapeutic strategies aimed at protection or cell replacement in degenerative, traumatic and ischemic disorders. The application of multipotent and pluripotent cells of different origins in vivo, as well as their use in the first preclinical and clinical trials, has brought new hope for patients and, as a near-term goal, aims to translate cell-based therapy to the clinic.

$82(7), 865-875$ (2006).

5: J. W. McDonald, X. Z. Liu, Y. Qu, S. Liu, S. K. Mickey, D. Turetsky, D. I. Gottlieb and D. W. Choi, Nature medicine 5 (12), 1410-1412 (1999).

6: G. I. Nistor, M. O. Totoiu, N. Haque, M. K. Carpenter and H. S. Keirstead, Glia 49 (3), 385-396 (2005).

7: Y. Ogawa, K. Sawamoto, T. Miyata, S. Miyao, M. Watanabe, M. Nakamura, B. S. Bregman, M. Koike, Y. Uchiyama, Y. Toyama and H. Okano, Journal of neuroscience research 69 (6), 925-933 (2002). 
8: H. Lee, G. A. Shamy, Y. Elkabetz, C. M. Schofield, N. L. Harrsion, G. Panagiotakos, N. D. Socci, V. Tabar and L. Studer, Stem cells 25 (8), 1931-1939 (2007).

9: N. Kozubenko, K. Turnovcova, M. Kapcalova, O. Butenko, M. Anderova, V. Rusnakova, M. Kubista, A. Hampl, P. Jendelova and E. Sykova, Cell transplantation 19 (4), 471-486 (2010).

10: C. Seminatore, J. Polentes, D. Ellman, N. Kozubenko, V. Itier, S. Tine, L. Tritschler, M. Brenot, E. Guidou, J. Blondeau, M. Lhuillier, A. Bugi, L. Aubry, P. Jendelova, E. Sykova, A. L. Perrier, B. Finsen and B. Onteniente, Stroke; a journal of cerebral circulation 41 (1), 153-159 (2010).

11: G. Gowing and C. N. Svendsen, Neurotherapeutics: the journal of the American Society for Experimental NeuroTherapeutics 8 (4), 591-606 (2011).

12: D. M. Deshpande, Y. S. Kim, T. Martinez, J. Carmen, S. Dike, I. Shats, L. L. Rubin, J. Drummond, C. Krishnan, A. Hoke, N. Maragakis, J. Shefner, J. D. Rothstein and D. A. Kerr, Ann Neurol 60 (1), 32-44 (2006).

13: D. C. Yohn, G. B. Miles, V. F. Rafuse and R. M. Brownstone, J Neurosci 28 (47), 12409-12418 (2008).

14: W. S. Toh, E. H. Lee, X. M. Guo, J. K. Chan, C. H. Yeow, A. B. Choo and T. Cao, Biomaterials 31 (27), 6968-6980 (2010).

15: I. Kehat, L. Khimovich, O. Caspi, A. Gepstein, R. Shofti, G. Arbel, I. Huber, J. Satin, J. Itskovitz-Eldor and L. Gepstein, Nature biotechnology 22 (10), 1282-1289 (2004)

16: N. S. Hwang, S. Varghese, H. J. Lee, Z. Zhang, Z. Ye, J. Bae, L. Cheng and J. Elisseeff, Proc Natl Acad Sci U S A 105 (52), 20641-20646 (2008).

17: E. J. Lee, L. Xu, G. H. Kim, S. K. Kang, S. W. Lee, S. H. Park, S. Kim, T. H. Choi and H. S. Kim, Biomaterials 33 (29), 7039-7046 (2012)

18: S. Horiguchi, J. Takahashi, Y. Kishi, A. Morizane, Y. Okamoto, M. Koyanagi, M. Tsuji, K. Tashiro, T. Honjo, S. Fujii and N. Hashimoto, Journal of neuroscience research 75 (6), 817-824 (2004).

19: R. M. Burnstein, T. Foltynie, X. He, D. K. Menon, C. N. Svendsen and M. A. Caldwell, The international journal of biochemistry \& cell biology 36 (4), 702-713 (2004)

20: P. Brundin, R. E. Strecker, F. H. Gage, O. Lindvall and A. Bjorklund, Annals of the New York Academy of Sciences 537, 148-160 (1988).

21: D. J. Clarke, P. Brundin, R. E. Strecker, O. G.
Nilsson, A. Bjorklund and O. Lindvall, Experimental brain research. Experimentelle Hirnforschung. Experimentation cerebrale 73 (1), 115-126 (1988).

22: O. Lindvall, P. Brundin, H. Widner, S. Rehncrona, B. Gustavii, R. Frackowiak, K. L. Leenders, G. Sawle, J. C. Rothwell, C. D. Marsden and et al., Science 247 (4942), 574-577 (1990).

23: K. Pollock, P. Stroemer, S. Patel, L. Stevanato, A. Hope, E. Miljan, Z. Dong, H. Hodges, J. Price and J. D. Sinden, Exp Neurol 199 (1), 143-155 (2006).

24: D. Arboleda, S. Forostyak, P. Jendelova, D. Marekova, T. Amemori, H. Pivonkova, K. Masinova and E. Sykova, Cell Mol Neurobiol 31 (7), 11131122 (2011).

25: D. S. Krause, Gene therapy 9 (11), 754-758 (2002).

26: E. Mezey, K. J. Chandross, G. Harta, R. A. Maki and S. R. McKercher, Science 290 (5497), 17791782 (2000).

27: D. J. Prockop, Science 276 (5309), 71-74 (1997).

28: Y. Li, J. Chen, X. G. Chen, L. Wang, S. C. Gautam, Y. X. Xu, M. Katakowski, L. J. Zhang, M. Lu, N. Janakiraman and M. Chopp, Neurology 59 (4), 514523 (2002).

29: J. Zhang, Y. Li, J. Chen, M. Yang, M. Katakowski, M. Lu and M. Chopp, Brain research 1030 (1), 1927 (2004).

30: A. Vercelli, O. M. Mereuta, D. Garbossa, G. Muraca, K. Mareschi, D. Rustichelli, I. Ferrero, L. Mazzini, E. Madon and F. Fagioli, Neurobiology of disease 31 (3), 395-405 (2008).

31: W. Gu, F. Zhang, Q. Xue, Z. Ma, P. Lu and B. Yu, Neuropathology : official journal of the Japanese Society of Neuropathology 30 (3), 205-217.

32: A. Uccelli, F. Benvenuto, A. Laroni and D. Giunti, Best Pract Res Clin Haematol 24 (1), 59-64.

33: A. La Spada and L. P. Ranum, Hum Mol Genet 19 (R1), R1-3 (2010).

34: L. Urdzikova, P. Jendelova, K. Glogarova, M. Burian, M. Hajek and E. Sykova, Journal of neurotrauma 23 (9), 1379-1391 (2006).

35: E. Sykova and P. Jendelova, Cell death and differentiation 14 (7), 1336-1342 (2007).

36: A. Hejcl, J. Sedy, M. Kapcalova, D. A. Toro, T. Amemori, P. Lesny, K. Likavcanova-Masinova, E. Krumbholcova, M. Pradny, J. Michalek, M. Burian, M. Hajek, P. Jendelova and E. Sykova, Stem cells and development 19 (10), 1535-1546.

37: M. Ohta, Y. Suzuki, T. Noda, Y. Ejiri, M. Dezawa, K. Kataoka, H. Chou, N. Ishikawa, N. Matsumoto, Y. Iwashita, E. Mizuta, S. Kuno and C. Ide, Exp Neurol 187 (2), 266-278 (2004).

38: A. M. Parr, I. Kulbatski, T. Zahir, X. Wang, C. Yue, 
A. Keating and C. H. Tator, Neuroscience 155 (3), 760-770 (2008).

39: X. Zeng, Y. S. Zeng, Y. H. Ma, L. Y. Lu, B. L. Du, W. Zhang, Y. Li and W. Y. Chan, Cell Transplant.

40: M. Chopp, X. H. Zhang, Y. Li, L. Wang, J. Chen, D. Lu, M. Lu and M. Rosenblum, Neuroreport 11 (13), 3001-3005 (2000).

41: L. Mazzini, K. Mareschi, I. Ferrero, E. Vassallo, G. Oliveri, N. Nasuelli, G. D. Oggioni, L. Testa and F. Fagioli, Journal of the neurological sciences 265 (12), 78-83 (2008).

42: S. Forostyak, P. Jendelova, M. Kapcalova, D. Arboleda and E. Sykova, Cytotherapy 13 (9), 10361046 (2011).

43: Y. Li, J. Chen, L. Wang, L. Zhang, M. Lu and M. Chopp, Neuroscience letters 316 (2), 67-70 (2001).

44: A. Kranz, D. C. Wagner, M. Kamprad, M. Scholz, U. R. Schmidt, F. Nitzsche, Z. Aberman, F. Emmrich, U. M. Riegelsberger and J. Boltze, Brain research 1315, 128-136 (2010).

45: H. C. Quevedo, K. E. Hatzistergos, B. N. Oskouei, G. S. Feigenbaum, J. E. Rodriguez, D. Valdes, P. M. Pattany, J. P. Zambrano, Q. Hu, I. McNiece, A. W. Heldman and J. M. Hare, Proc Natl Acad Sci U S A 106 (33), 14022-14027 (2009).

46: M. Dubsky, A. Jirkovska, R. Bem, L. Pagacova, V. Fejfarova, M. Varga, J. Skibova, S. Langkramer and E. Sykova, Vnitrni lekarstvi 57 (5), 451-455 (2011).

47: V. Schachinger, S. Erbs, A. Elsasser, W. Haberbosch, R. Hambrecht, H. Holschermann, J. Yu, R. Corti, D. G. Mathey, C. W. Hamm, T. Suselbeck, N. Werner, J. Haase, J. Neuzner, A. Germing, B. Mark, B.
Assmus, T. Tonn, S. Dimmeler, A. M. Zeiher and R.A. Investigators, European heart journal 27 (23), 2775-2783 (2006).

48: O. Y. Bang, J. S. Lee, P. H. Lee and G. Lee, Ann Neurol 57 (6), 874-882 (2005).

49: E. Sykova, A. Homola, R. Mazanec, H. Lachmann, S. L. Konradova, P. Kobylka, R. Padr, J. Neuwirth, V. Komrska, V. Vavra, J. Stulik and M. Bojar, Cell transplantation 15 (8-9), 675-687 (2006).

50: J. Vaquero and M. Zurita, Progress in neurobiology 93 (3), 341-349 (2011).

51: L. Mazzini, K. Mareschi, I. Ferrero, M. Miglioretti, A. Stecco, S. Servo, A. Carriero, F. Monaco and F. Fagioli, Cytotherapy (2011).

52: J. T. Dimos, K. T. Rodolfa, K. K. Niakan, L. M. Weisenthal, H. Mitsumoto, W. Chung, G. F. Croft, G. Saphier, R. Leibel, R. Goland, H. Wichterle, C. E. Henderson and K. Eggan, Science 321 (5893), 1218-1221 (2008).

53: M. Wernig, J. P. Zhao, J. Pruszak, E. Hedlund, D. Fu, F. Soldner, V. Broccoli, M. Constantine-Paton, O. Isacson and R. Jaenisch, Proc Natl Acad Sci U S A 105 (15), 5856-5861 (2008).

54: H. Gai, E. L. Leung, P. D. Costantino, J. R. Aguila, D. M. Nguyen, L. M. Fink, D. C. Ward and Y. Ma, Cell biology international 33 (11), 1184-1193 (2009).

55: M. Gomi, Y. Takagi, A. Morizane, D. Doi, M. Nishimura, S. Miyamoto and J. Takahashi, Brain research 1459, 52-60 (2012).

56: H. Wichterle and S. Przedborski, Nature neuroscience 13 (7), 800-804 (2010).

\section{[Acknowledgements]}

This study was supported by the grants AV0Z50390703, GA CR 304/11/0189 and P304/12/G0691. We thank James Dutt for language editing. 


\section{Comment from the Editor-in-Chief}

The scope of Laser Therapy has gradually increased dramatically from its first days as being dedicated to all aspects of low level laser (now light) therapy and photobioactivation, simply through having attracted as the journal supporters a large number of international societies, whose individual and highly eclectic scopes have been added to that of the original journal. However, laser and light-related topics remain our remit: so why then did I agree to publish this excellent article on stem cells in regenerative medicine by Profs Sykova and Forostyak, which has no immediately apparent connection with laser medicine and surgery?

Two reasons: first, because stem cells represent an exciting and fast expanding field and we all need to be doing our best to keep up with the leaps and bounds being made in any filed, even those not immediately connected with our own; the second reason is to look to the future and see if and how we could make that vital connection and integrate laser and light energy into the stem cell field: we cannot possibly do that without the understanding generated by a first class review paper such as this to whet our appetite and propel us to take the step whereby stem cell regenerative medicine might be enhanced with the addition of LLLT.

Stem cells have a huge potential but have two large obstacles to their application: the very small number of cells which can be harvested per one indication, and the ability to maintain stem cell 'banks' from which cells may be selected for particular tasks, while maintaining the specific multi- or pluripotential of the cells. I believe in my heart that LLLT can help with both of these aspects, so I am extending the challenge to you, our Laser Therapy readers: have you already tried to expand a stem cell culture using LLLT? Have you maintained a stem cell culture for prolonged periods under LD or more probably LED energy while maintaining the specific characteristics which make stem cells so excitingly unique? The field is wide open .... Let's explore the potentials. The benefits for medicine and mankind could be huge, with a minimal amount of equipment required.

The contents of this article were originally presented as an oral paper at Laser Florence 2012 on November 10th 2012 in Florence, Italy. 